海綿静脈洞部の手術

一動眼，滑車，外転神経の温存について一

後藤 剛夫，大畑＼cjkstart建治

大阪市立大学脳神経外科

\title{
Surgical Excision for Cavernous Sinus Tumors
}

\author{
Takeo Goto, M.D., and Kenji Ohata, M.D. \\ Department of Neurosurgery, Osaka City University Graduate School of Medicine
}

Although stereotactic radiosurgery is a basic treatment for cavernous sinus tumors, surgical excision is required in patients with symptomatic tumors or recurrent tumors after radiotheraphy. Here, we present detailed anatomical knowledge of the cavernous sinus and surgical techniques for preservation of the third, fourth and sixth cranial nerves. Our surgical procedure for cavernous sinus tumor is an option for the treatment of cavernous sinus tumors.

(Received April 2, 2019; accepted April 16, 2019)

Key words : cavernous sinus tumor, surgery, petrosal approach, endoscopic endonasal approach Jpn J Neurosurg（Tokyo）28:398-406, 2019

\section{はじめに}

海綿静脈洞部腫瘍に対しては，1980 年代後半に多くの 頭蓋底外科医により積極的な切除が試みられた ${ }^{1 / 2) 4)}$ 。し かし眼球運動障害の悪化など治療成績の悪さから, その 後定位放射線照射が治療の中心となっている315)6)8).し かし海綿静脈洞部腫瘍の中には放射線照射後の再増大や 発見時すでに眼球運動障害など症候性となっている腫瘍 も存在する。また発見時に視索, 視交叉を強く圧迫して いる腫瘍もある。こうした例では, 眼球運動障害をきた さず腫瘍体積が縮小できる切除法があれば手術切除を検 討することになる。 われわれは最近, 海綿静脈洞の解剖 学的特徴を考慮した安全な手術到達法で眼球運動を温存 したうえで腫瘍減圧を行っているので，手技の詳細を海 綿静脈洞部髄膜腫と海綿静脈洞部軟骨肉腫の 2 つに分け て説明する。また今回の報告では, 蝶形骨縁髄膜腫や錐
体斜台部髄膜腫が海綿静脈洞内に部分進展したものは除 外している。

\section{海綿静脈洞部䯣膜腫の手術}

\section{1 手術適応}

海綿静脈洞部髄膜腫の治療では基本的には定位放射線 照射を第 1 選択としている。しかし放射線照射後再発例, 眼球運動障害が強い症候性例，および視索，視交叉を圧 迫するような上方あるいは内側進展がある腫瘍を手術適 応としている。

\section{2 手術法を考えるうえで重要な海綿静脈洞解剖 の特徵}

海綿静脈洞を頭側から観察するとその上壁は，内側は 前床突起と後床突起を結ぶ interclinoid ligament（ICL），

連絡先：後藤剛夫， $=545-8585$ 大阪市阿倍野区旭町 1-4-3 大阪市立大学脳神経外科

Address reprint requests to: Takeo Goto, M.D., Department of Neurosurgery, Osaka City University Graduate School of Medicine, 1-4-3 Asahimachi, Abeno-ku, Osaka-shi, Osaka 545-8585, Japan 
外側は前床突起と錐体先端部をつなぐ anterior petroclinoid ligament (APCL), 後壁は後床突起と錐体先端部を つなぐ posterior petroclinoid ligament（PPCL）で囲まれ た頂点を前方に向けた三角形の形状をしている．海綿静 脈洞を貫通するそれぞれの脳神経は動眼神経は上壁を， 外転神経は後壁を, 滑車神経, 三叉神経は外側壁を貫通 して海綿静脈洞内に入っているが，後方ではそれぞれの 脳神経間の距離が比較的広いことがわかる (Fig. 1)。一 方海綿静脈洞を前方に進むにつれてそれぞれの脳神経の 間隔が狭くなり最終的に上眼窩裂を貫通して眼窩内へと 走行している。また動眼神経は必ず APCLょり内側で海 綿静脈洞内一と走行し, 滑車神経は海綿静脈洞外敗壁を APCL の外側を伴走している。また外転神経は PPCL の 下方へ通って海綿静脈洞へと走行しているという特徵が ある。これらは手術法を検討するうえで非常に重要な情 報である。

\section{3 海綿静脈洞解剖に基づいた手術法の選択}

1980 年代後半に報告された海綿静脈洞部への到達法 は, 前頭側頭開頭を行った後, 上眼窩裂で meningoorbital band を切開し, 海綿静脈洞外側壁固有硬膜を剝離して動 眼，滑車，三叉神経を同定，それぞれの神経間から腫瘍 を切除するのが基本であった ${ }^{1224)}$ 。こうした手術法は前 頭側頭開頭の変法であり, 脳神経外科医にとつて解剖学 的理解が容易な到達法ではあるが, 神経間距離が狭い前 方から腫瘍切除を開始することや，いきなり腫瘍浸潤を 受けている脳神経前方部から腫瘍剝離を進めるため, 手 術により脳神経機能が悪化する危険が非常に高いもので あった ${ }^{12) 4}$ ．そこでわれわれは脳神経間距離が広い後方 から海綿静脈洞内に進入し前方へと腫瘍を剝離すること を試みている ${ }^{7)}$. 後方から剝離を進めると, 通常後頭蓋 窩では動眼, 滑車, 外転神経の同定が容易でかつ腫瘍と の癒着も少ないため, 剝離操作そのものも容易になる. われわれは後方から腫瘍に到達する手術法として骨削除 範囲をできるだけ抑えた最小合併経錐体到達法を好んで 用いている7).

\section{4 最小合併経錐体到達法による腫瘍切除}

患者は park-bench position として頭部を固定後, 耳介 を囲む皮膚切開を行い, その後, 側頭開頭に一部後頭下 開頭を加えた側頭後頭下開頭を行っている. 後頭下開頭 は $\mathrm{S}$ 状静脈洞上部が部分露出できれば十分である（Fig. $2 \mathrm{~A}, \mathrm{~B})$. その後中頭蓋底硬膜と $\mathrm{S}$ 状静脈洞前方硬膜を錐 体骨から剥離した後, 錐体骨縁のみをダイヤモンドドリ ルで削除して骨削除は終了している(Fig. 2C)。骨削除の

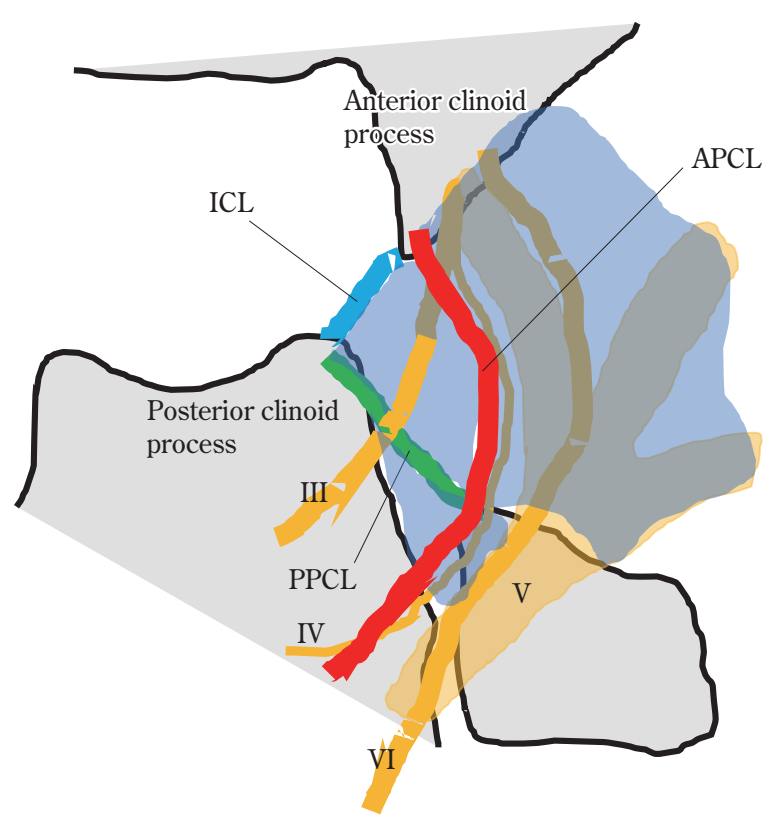

Fig. 1 Illustration showing the anatomical relation of the cranial nerves and the cavernous sinus

The distance between each cranial nerve is wider in the posterior part of the cavernous sinus.

目安は上錐体静脈洞が前方から後方まで露出できれば十 分である. 次に側頭硬膜を三叉神経外側に向かって切開 する. 次に S 状静脈洞の前方で後頭蓋窩硬膜を切開し, この切開を錐体骨縁に沿って前方に延長する，後頭蓋窩 側で錐体静脈を確認し, 錐体静脈の上錐体静脈洞への流 入点よりも前方で上錐体静脈洞を結紮する。続いて三叉 神経第三枝外側で硬膜を切開し，そのままメッケル腔を 開放する，同時に三叉神経に沿って海綿静脈洞外側壁を 後方から前方へと固有硬膜の層で剝離を進める。次に小 脳テントを滑車神経の海綿静脈洞への貫通部の後方で切 開する. 次に側頭葉を上方に牽引儿, 後方から前方を観 察すると, 海綿静脈洞を後方から前方に観察できる術野 となる (Fig. 2D) 。海綿静脈洞外側壁固有硬膜を十分に 㓦離すると三叉神経第一〜三枝, 滑車神経が外側壁で確 認できる。 また滑車神経のすぐ内側にはテント縁から連 続する線維性の靯帯が前床突起へと連なる APCL が確認 できる。たとえ海綿静脈洞内すべてを髄膜腫が占拠して いてもこの勒帯構造は保たれていることがほとんどであ るため, この靱帯を後方から前方へとたどると前床突起 先端を同定することができる。また APCLの外側の滑車 神経，内側の動眼神経を同定できるよい指標となる，通 常この時点で視神経と内頝動脈 $\mathrm{C} 2$ 部も確認できること になる．また後方から腫瘍切除を始めるとテント縁から 後床突起へと連続する PPCL を確認することも比較的容 

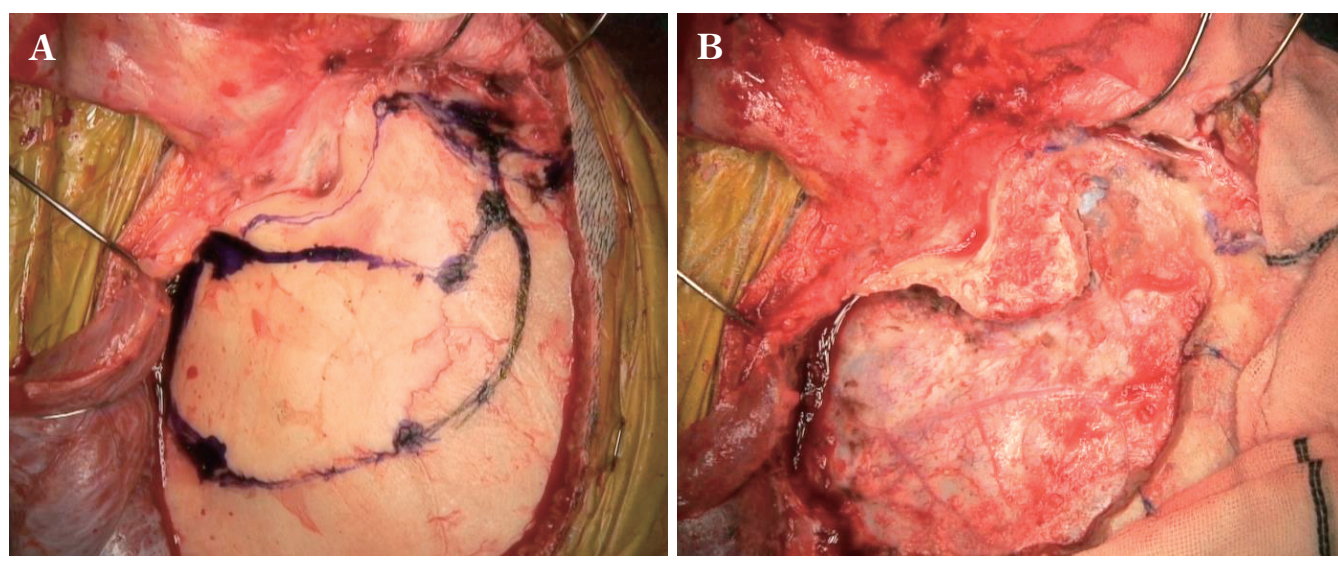

$\mathrm{C}$

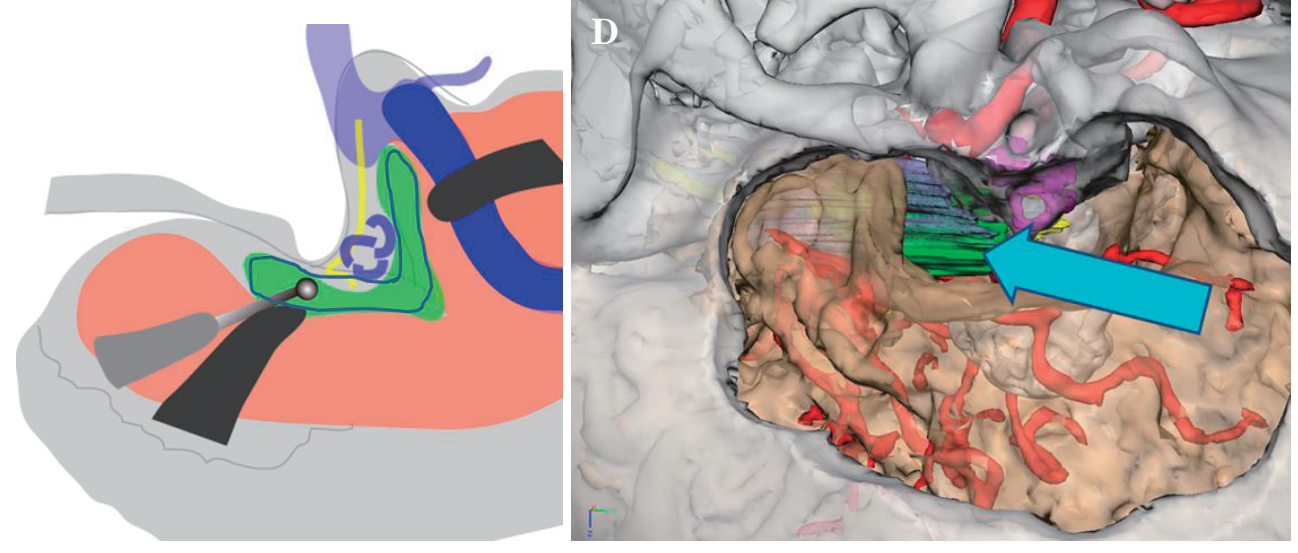

Fig. 2 Mid-anterior and posterior combined petrosal approach

A, B : Temporal and small suboccipital craniotomy was performed for exposure of the sigmoid sinus.

C : Small amount of petrosectomy along the petrous ridge. The blue circle shows the extent of petrosectomy along the petrous ridge.

D : Surgical corridor to the cavernous sinus meningioma.

易である。この勒帯の下方を外転神経が走行しているこ とを理解すると不用意に外転神経を損傷することもな い. PPCLを内側へと追いかけると後床突起を容易に確 認できる。海綿静脈洞髄膜腫は勒帯構造である APCL, PPCLが保たれていると, テントの骨組みのように勒帯 が腫瘍の形状を支えているため, 内減圧を行っても容易 に腫瘍を回転させることができない.しかしこれら $2 つ$ の勒帯構造を確認, 切断すると腫瘍は容易に回転, 毫引 できるようになり動眼, 滑車, 外転神経からの剝離操作 が容易になる。

通常滑車神経と三叉神経第一枝の間から腫場内減圧を 始める，腫瘍を減圧すると滑車神経を下方に移動させる ことができるため次に滑車神経と動眼神経の間を拡大さ せることができる，この時点で APCLを切断すると, 腫 瘍を下方に毫引しやすくなり腫瘍と動眼神経の境界も確 認できるようになる。この到達法では動眼神経の海綿静 脈洞入口部より前方あるいは内側の腫瘍摘出は困難であ
る。また後方では PPCL を切開し，後頭蓋窩側に突出し た腫瘍を回転させながら外転神経との虽離を行う。しか し内頝動脈 C 5 部周囲に薄く腫瘍を残すため外転神経と 腫瘍の完全剝離は不可能である. 以上の手術操作で摘出 が不可能な部位は動眼神経の内側, 前方の腫瘍, 内頚動 脈 C4〜 5 部周囲の腫瘍である.この手術の目的が神経機 能を温存したうえでの最大切除であることを考えるとこ の時点で手術操作を終了するべきであると考えている.

これまでのわれわれの経験では海綿静脈洞随膜腫は比 較的疎な空間がある海綿静脈洞後方部に進展する傾向が あるため, 同到達法で腫瘍の 8 割程度を摘出することが 可能である ${ }^{7)}$. 海綿静脈洞内側の腫瘍が大きく視神経視 交叉圧迫が残存している場合には経鼻内視鏡下に二期的 手術を追加している.

\section{症例提示 1}

42 歳女性, 6 力月前から続く右動眼神経麻痺による複 視のため来院した。来院時右動眼神経麻痺を認めた。造 

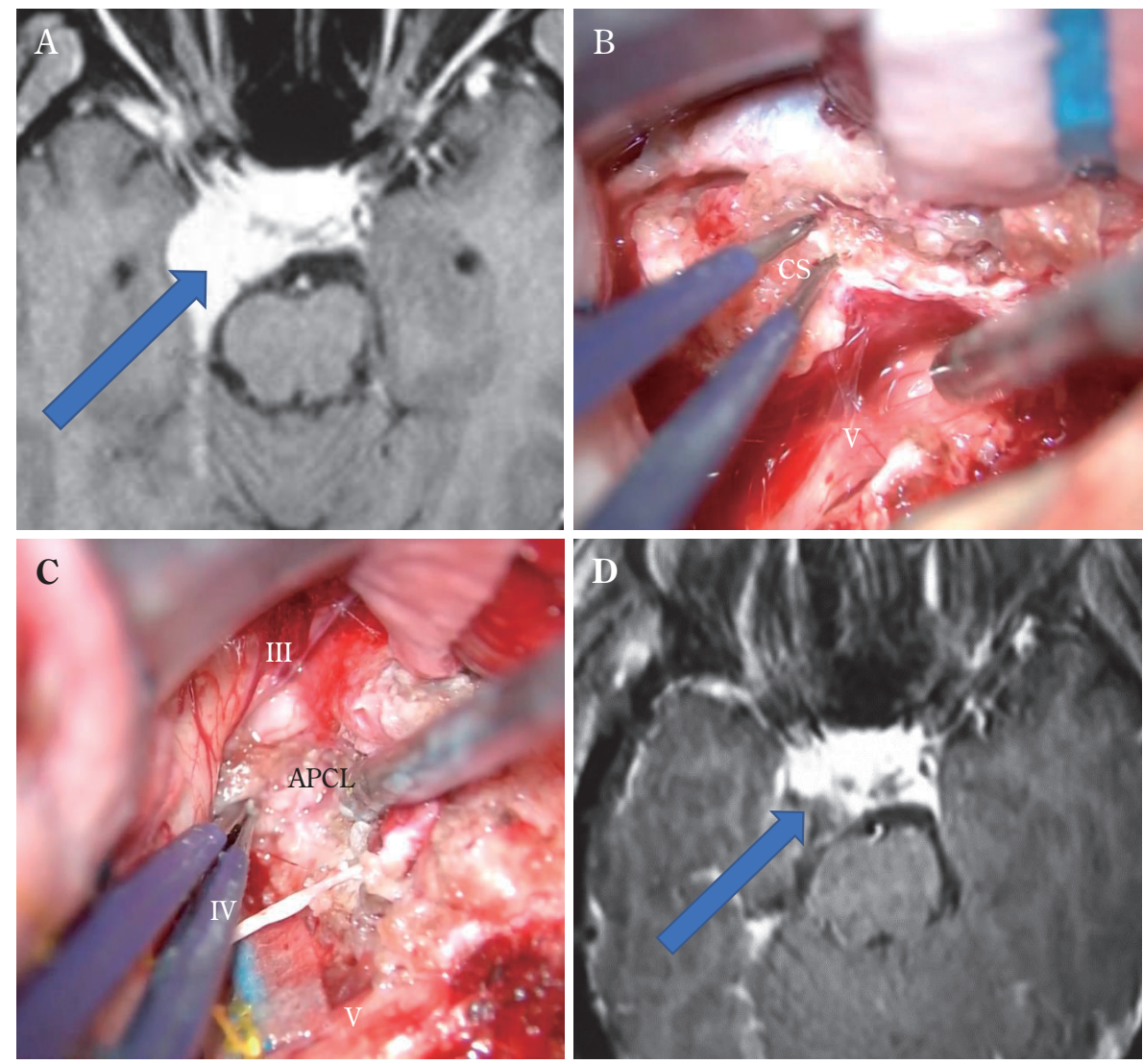

Fig. 3 Surgical excision of the cavernous sinus meningioma
A : Preoperative magnetic resonance image.
B : Intraoperative photograph showing the trigeminal nerve and the cavernous sinus tumor.
C : The third, fourth and fifth nerves were anatomically preserved after the removal of the cavernous sinus meningioma.
D : Postoperative magnetic resonance image.

影 MRI では海綿静脈洞後方部を中心に䯣膜腫と思われ る病変を認めた（Fig. 3A）。動眼神経症状の改善を目指 して最小合併錐体到達法による腫䬗摘出を行つた。初め にメッケル腔を開放し後方から海綿静脈洞の腫愓を摘出 した（Fig. 3B)．APCLを指標に後方から滑車，動眼神経

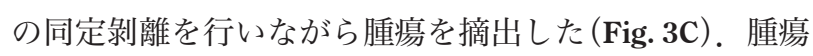
の大部分は摘出でき (Fig. 3D), また患者動眼神経機能 は正常化した（Fig.4).

\section{5 経鼻内視鏡下到達法}

動眼神経の海綿静脈洞入口部よりも内側あるいは前方 に存在する腫崵に対しては経鼻内視鏡下の腫瑒摘出が非 常に有用である. 通常の経鼻内視鏡下到達法でトルコ鞍 底に到達した後, トルコ鞍底, 鞍結節, 病変側視神経管, 病変側海綿静脈洞前壁, 下壁を広くドリルで削除する。 また斜台上部を丁寧に削除して傍斜台部内頝動脈を露出
する. さらに後床突起, 鞍背も削除しておく。つまり海 綿静脈洞を中心に広く骨構造を丁寧にドリルで削除して おくことが重要である。海綿静脈洞葡膜腫は当然ではあ るが, 海綿静脈洞前壁，下壁，鞍隔膜，視神経管下壁硬 膜，斜台上部硬膜に広く付着部をもつため, これらの硬 膜を露出して硬膜凝固を行うことで止血のきいた術野で 手術を行元る利点がある。また同部の硬膜を切開すると 腫福が付着部から離断でき，回転させやすくなるという 特徴がある。次にトルコ鞍底硬膜を病変側で切開し, 下 垂体を対側に牽引すると海綿静脈洞内側の腫揚が露出で きる。海綿静脈洞内側の腫愓を安全にかつ十分に切除す るためには鞍隔膜および ICLを切開することが重要であ る。鞍隔膜と ICL を切開すると腫瑒が内側掞よび下方に 移動しやすくなり，腫場外側の動眼神経を同定しやすく なる。こうして海綿静脈洞内側の腫噋も経鼻内視鏡下に 摘出が可能になった。動眼神経を同定し，視神経，視交 


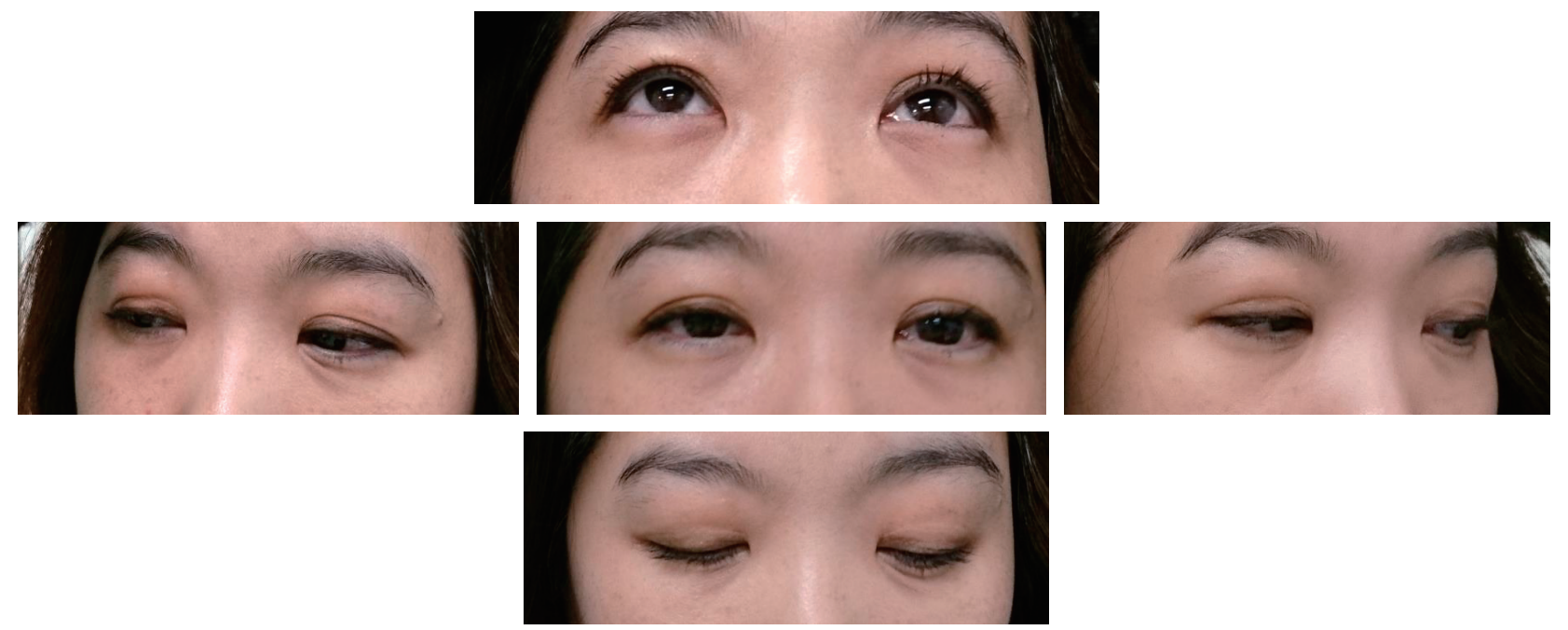

Fig. 4 Photographs showing her fully recovered eye movement

叉，視索周囲の腫瘍を摘出できた時点で手術を終了して いる。しかし内頝動脈に付着する腫瘍についてはわずか に残存させることになる。

\section{症例提示 2}

40 歳女性, 左眼視野障害を主訴に来院した。入院時左 眼鼻側半盲を認めた。造影 MRIでは左海綿静脈洞内側部 に腫瘍を認めた（Fig. 5A）。経鼻内視鏡下に海綿静脈洞 内側腫瘍を摘出した (Fig. 5B)。腫瘍を下方に牽引しな がら, 視神経, 内頝動脈, 動眼神経, 外転神経と順次剝 離操作を行い, 腫瘍を摘出した (Fig. 6A-C). 術後内側 部腫瘍は摘出できた。また眼球運動機能を温存できた

(Fig. 7).

\section{海綿静脈洞部䯣膜腫に対する手術のまとめ}

最小合併経錐体到達法および経鼻内視鏡手術の組み合 わせで腫瘍体積を安全に減らすことが可能になったが, 全摘出を目指す手術ではないことを強調したい. あくま で腫瘍減圧による神経症状の改善あるいはその後の定位 放射線照射を行いやすくするための治療であることを忘 れてはならない，腫瘍の硬さなど手術所見により切除度 を調整する判断が重要であり, 無理な切除による神経機 能の悪化は避けなければならないことを強調したい.

\section{海綿静脈洞部軟骨肉腫の手術}

頭蓋底軟骨肉腫はときに海綿静脈洞内を占拠して動 眼，外転神経麻痺など複視を主訴に発症する場合があ る。石灰化を伴う大きな腫瘍が海綿静脈洞内にあると腫
瘍と脳神経を䟝離して腫瘍を摘出することはきわめて難 しいよう思われる。しかし髄膜腫と異なり発生部位を考 慮するとこの腫瘍は経鼻内視鏡下に比較的安全に神経機 能を悪化させることなく摘出可能であることがわかって きた。経鼻内視鏡下に海綿静脈洞部軟骨肉腫を摘出する 方法について説明する。

\section{1 手術適応}

海綿静脈洞部軟骨肉腫では，髄膜腫と異なり無症候性 腫瘍の場合でもまずは手術による腫瘍切除を第 1 選択と している。腫瘍再発，残存腫瘍の再増大時に定位放射線 照射を含めた放射線照射を検討している。

\section{2 手術法を考えるうえで重要な海綿静脈洞解剖 の特徵}

海綿静脈洞を冠状断で観察すると下壁は骨膜硬膜で覆 われていることになる（Fig. 8A）。海綿静脈洞部軟骨肉 腫は海綿静脈洞下壁周辺の骨組織から発生し，この骨膜 硬膜に覆われたまま海綿静脈洞内に進展しているため, 直接脳神経に浸潤している可能性は比較的少ない（Fig. 8B).

\section{3 経鼻内視鏡下到達法}

海綿静脈洞下壁を構成する骨組織を広くドリルで削除 するためまず pterygoid process 基部を削除して側方の術 野を拡大させている。続いて傍斜台部内頝動脈の露出と 海綿静脈洞下壁，トルコ鞍底骨，斜台上部骨を丁寧にド リルで削除すると通常腫瘍が直接露出できる。腫瘍周囲 の骨構造を十分削除すると，正常硬膜の牽引が容易にな 

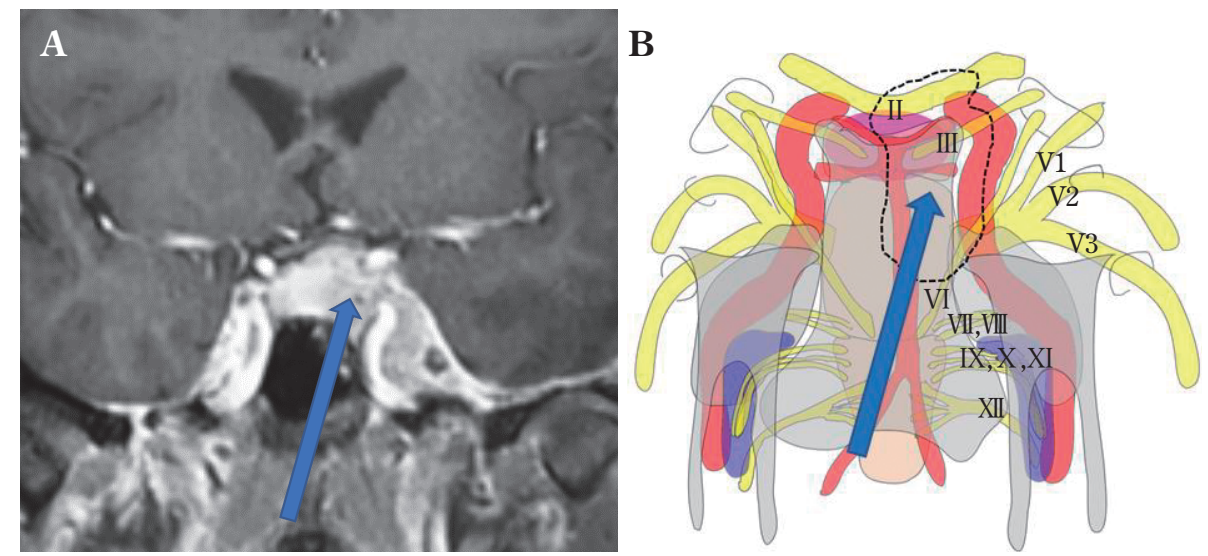

Fig. 5 Medial cavernous sinus meningioma compressing the optic nerve and the optic tract

A : Preoperative magnetic resonance image.

B : Surgical corridor to the medial cavernous sinus meningioma.
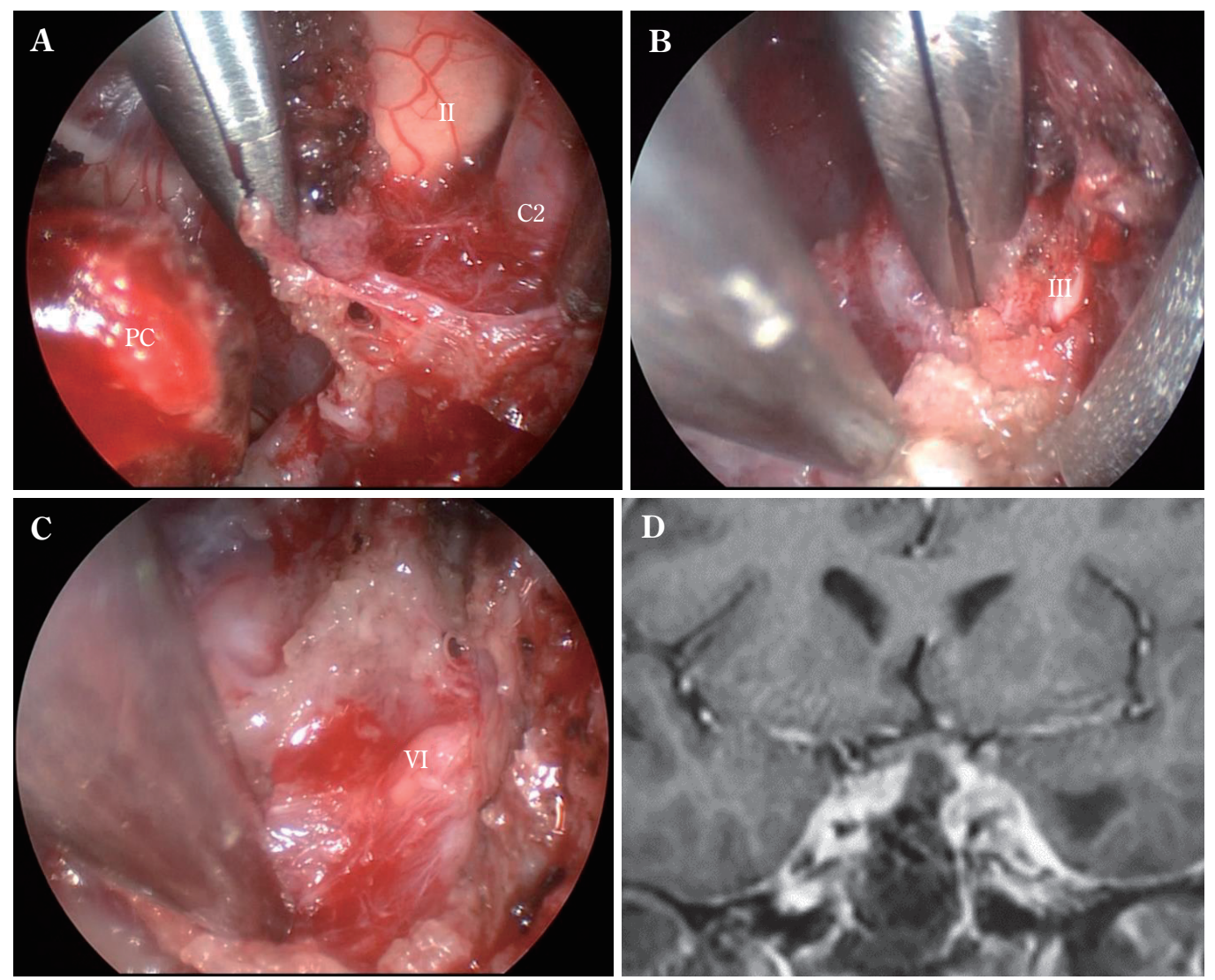

Fig. 6 A-C : Her left optic nerve, oculomotor nerve and abducent nerve were successfully decompressed via the endoscopic endonasal approach.

D : Postoperative magnetic resonance image. 


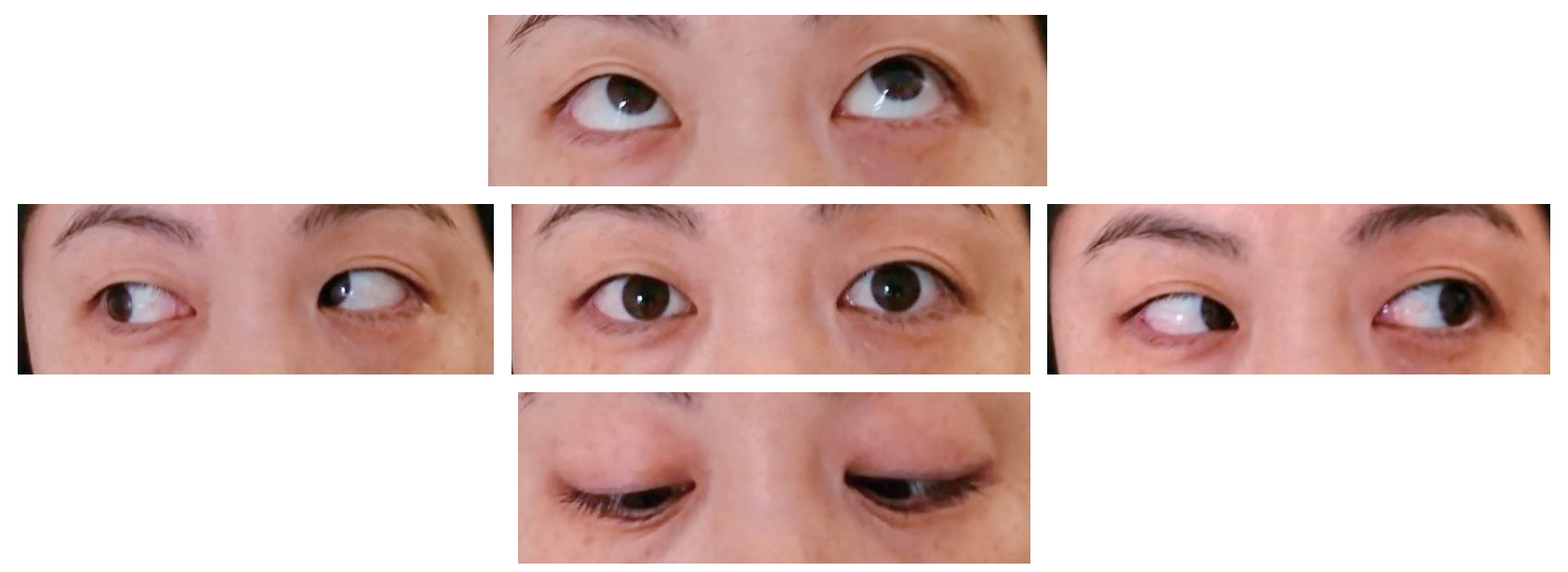

Fig. 7 Photographs showing her fully preserved eye movement

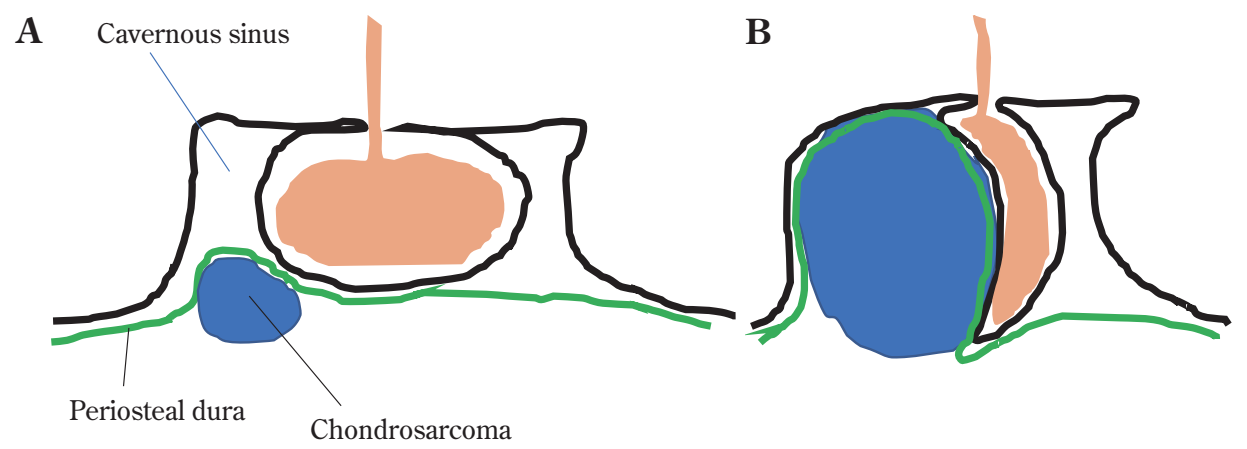

Fig. 8 Illustration showing the method for invading the cavernous sinus in case of chondrosarcoma

A : The tumor arises in the extradural space.

B : The tumor extended to the cavernous sinus covered with the osseous dural layer.

るため腫瘍境界を剝離しやすくなる，腫瘍と後床突起は 連続している場合が多いが同部の骨も硬膜外に切除する と硬い腫瘍も回転させやすくなる，海綿静脈洞下壁硬膜 はときには非常に薄くなり腫瘍が海綿静脈洞内に一部直 接進展していることもあるが, 経鼻内視鏡下に手術を行 うと同部膜構造が直接観察できるため, 腫瘍を下方に引 き出すようにすると脳神経を損傷することはない.

\section{症例提示 3}

22 歳男性，3 力月前から続く右外転神経麻痺による複 視を主訴に紹介となった。 入院時右完全外転神経麻痺を 認めた。画像上海綿静脈洞に大きな石灰化を伴う腫瘍を 認めた（Fig. 9)。経鼻内視鏡下に腫瘍を摘出しすべての 腫瘍を摘出した (Fig. 10)。術後外転神経麻痺は消失した

(Fig. 11).

\section{まとめ}

海綿静脈洞部腫瘍に対する手術治療において脳神経機 能をどのように温存するかについてわれわれの経験を中 心に説明した。しかし何度も強調するが，今回述べた海 綿静脈洞部髄膜腫，軟骨肉腫が手術切除のみで治癒でき るわけではない.このためどちらの腫瘍も神経機能の温 存を最重点に考えたうえで手術戦略を立てることが重要 である。

本論文は第 38 回日本脳神経外科コングレス総会において 発表させていただいた内容をまとめたものである.

\section{筆者の COI (conflicts of interest) 開示}

筆頭揖よび共同演者は日本脳神経外科学会への COI 自己申 告を完了しています。本演題の発表に関して開示すべき COI はありません。 


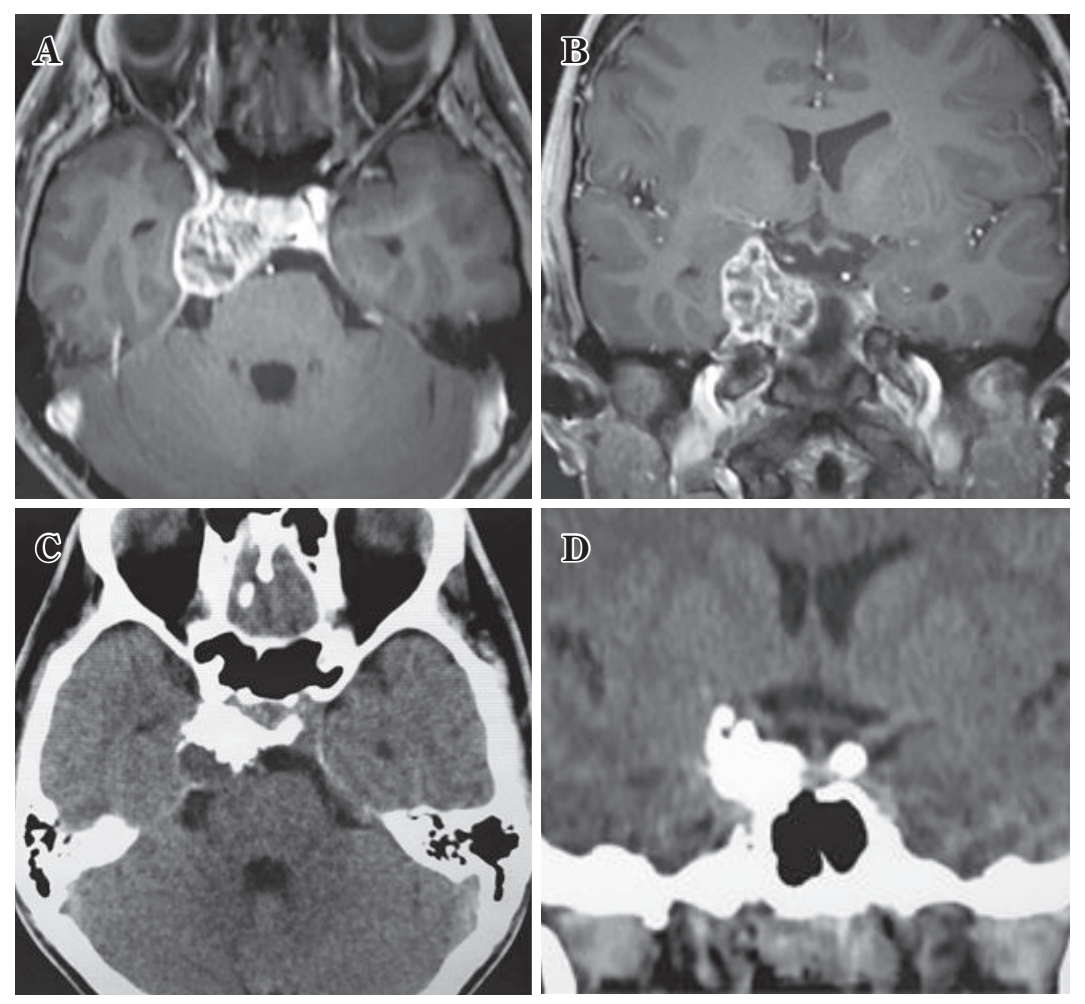

Fig. 9 Chondrosarcoma occupying the right cavernous sinus A, B : Preoperative magnetic resonance image.

C, D : Preoperative computed tomography.
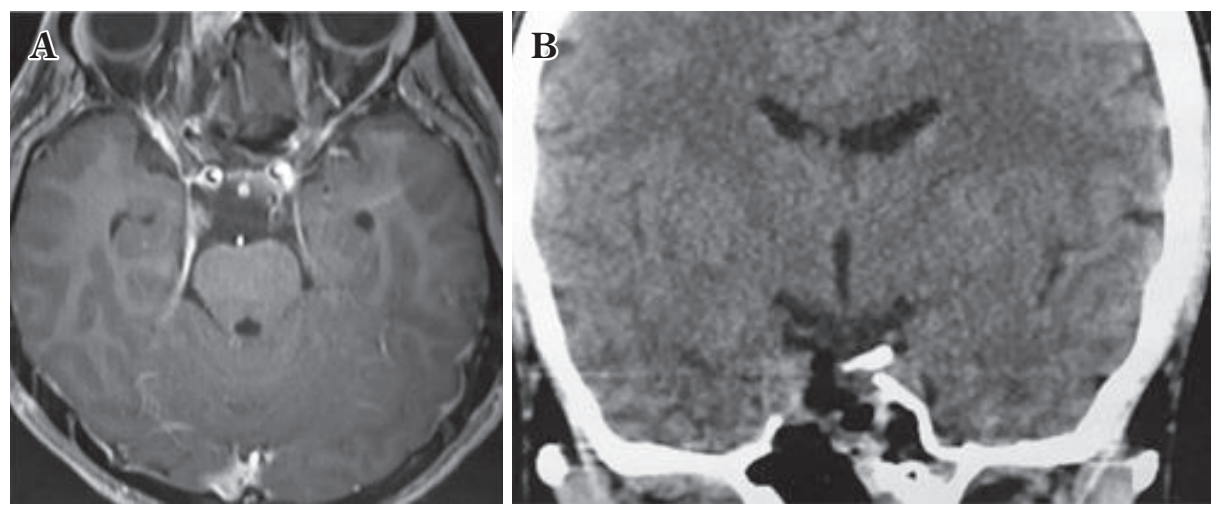

Fig. 10 Postoperative magnetic resonance image (A) and computed tomography (B)
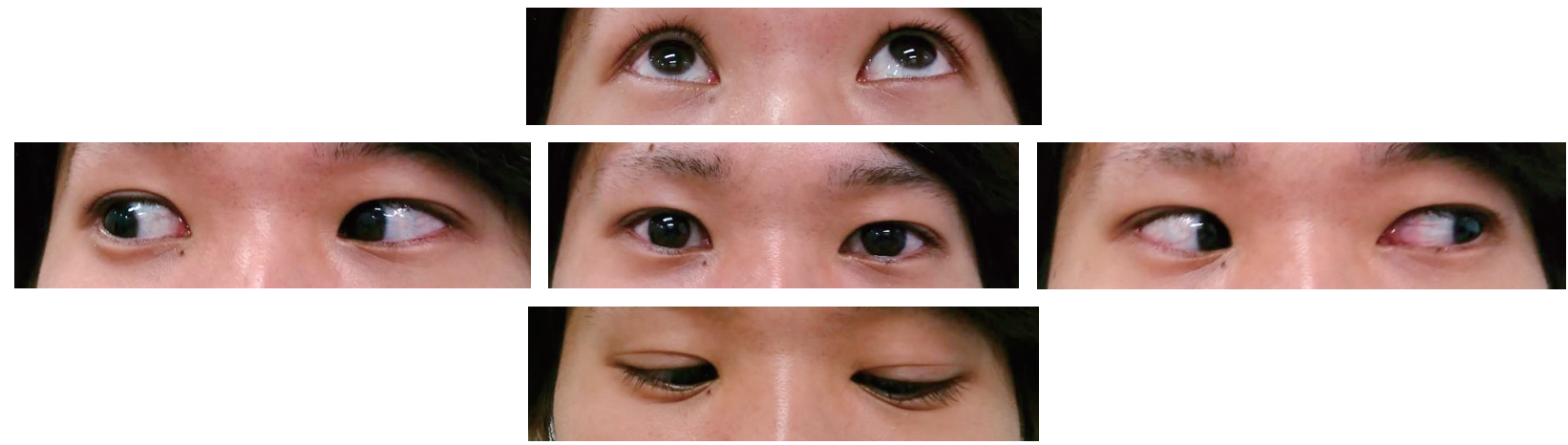

Fig. 11 Photographs showing his fully recovered eye movement 


\section{文献}

1) Dolenc V, Kregar T, Ferluga M, Fettich M, Morina A : Treatment of tumors invading the cavernous sinus. in Dolenc VV (ed): The Cavernous Sinus: A Multidisciplinary Approach to Vascular and Tumorous Lesions. Vienna, Springer, 1987, pp.377-391.

2) Hakuba A, Tanaka K, Suzuki T, Nishimura S : A combined orbitozygomatic infratemporal epidural and subdural approach for lesions involving the entire cavernous sinus. $J$ Neurosurg 71:699-704, 1989.

3) Hasegawa T, Kida Y, Yoshimoto M, Koike J, Iizuka H, Ishii D : Long-term outcomes of Gamma Knife surgery for cavernous sinus meningioma. J Neurosurg 107: 745-751, 2007.

4) Kawase T, Toya S, Shiobara R, Kimura C, Nakajima H : Skull base approaches for meningiomas invading the cavernous sinus. in Dolenc VV (ed): The Cavernous Sinus: A Multidisciplinary Approach to Vascular and Tumorou Lesions. Vienna, Springer, 1987, pp.346-354.

5) Lee CC, Trifiletti DM, Sahgal A, DeSalles A, Fariselli L,
Hayashi M, Levivier M, Ma L, Álvarez RM, Paddick I, Regis J, Ryu S, Slotman B, Sheehan J : Stereotactic radiosurgery for benign (World Health Organization Grade I ) cavernous sinus meningiomas - International Stereotactic Radiosurgery Society (ISRS) Practice Guideline: a systematic review. Neurosurgery $3: 1128-1142,2018$.

6) Lee JY, Niranjan A, McInerney J, Kondziolka D, Flickinger JC, Lunsford LD : Stereotactic radiosurgery providing longterm tumor control of cavernous sinus meningiomas. $J$ Neurosurg 97:65-72, 2002.

7) Morisako H, Goto T, Ohata H, Goudihalli SR, Shirosaka K, Ohata K : Safe maximal resection of primary cavernous sinus meningiomas via a minimal anterior and posterior combined transpetrosal approach. Neurosurg Focus 44 : E11, 2018.

8) Shin M, Kurita H, Sasaki T, Kawamoto S, Tago M, Kawahara N, Morita A, Ueki K, Kirino T : Analysis of treatment outcome after stereotactic radiosurgery for cavernous sinus meningiomas.J Neurosurg $\quad 95: 435-439,2001$.

海綿静脈洞部の手術一動眼, 滑車, 外転神経の温存について一

後藤 剛夫 大畑 建治

海綿静脈洞部腫瘍に対する治療としては定位放射線治療の役割が大きい. しかし放射線照射後の再 発や症候性腫瘍ではときに外科的切除が必要になることがある. 海綿静脈洞部髄膜腫, 軟骨肉腫の 2 つの疾患について解剖学的特徵を踏まえた腫瘍切除について解説した. 髄膜腫については後方から腫 瘍に到達する最小合併経錐体到達法が有用であった. また内側海綿静脈洞部髄膜腫, 海綿静脈洞部軟 骨肉腫は経鼻内視鏡手術での摘出が有用であった. 手術適応をよく検討すれば, 動眼, 滑車, 外転神 経機能を温存して腫瘍減圧ができることを説明した. 